\title{
MOLLUSCAN COMMUNITIES IN LATE HOLOCENE FLUVIAL DEPOSITS AS AN INDICATOR OF HUMAN ACTIVITY: A STUDY IN PODHALE BASIN IN SOUTH POLAND
}

\author{
WITOLD PAWEŁ ALEXANDROWICZ
}

Chair of Environmental Analysis and Cartography, AGH University of Science and Technology, Al Mickiewicza 30,30-059 Krakow, Poland; e-mail: wpalex@geol.agh.edu.pl, teska4@op.pl

\begin{abstract}
Alexandrowicz W.P.: Molluscan communities in Late Holocene fluvial deposits as an indicator of human activity: A study in Podhale basin in South Poland. Ekológia (Bratislava), Vol. 32, No. 1, p. $111-125,2013$.

The localities of Late Holocene fluvial sediments in the Podhale basin were subjected to malacological analysis. Two types of mollusc communities were found in these formations. The first type is characterized by a high proportion of species typical of open environments such as the zones of wide valleys. The predomination of shade-loving taxa is typical of the second type which is mainly associated with narrow, V-shaped type valleys. Malacological analysis allowed characterization of these communities and reconstruction of environmental changes over the last few hundred years. Particular attention was paid to the reconstruction of the history of human settlement in the Podhale region and its impact on the transformation of the environment. This impact resulted in massive deforestation and the introduction of wide-scale farming and pastoral practices. Application of this malacological analysis enabled the determination of the anthropogenic pressures, and changes in their intensity, over the last few hundred years.
\end{abstract}

Key words: molluscs, river sediments, anthropogenic pressure, Late Holocene, Podhale basin, South Poland.

\section{Introduction}

Molluscs are sensitive indicators of environmental conditions, and they constitute a group particularly suited to reconstruction of past changes in the nature of habitats and ecosystems, occurring as the effect of climate or human activity. Because of their relatively low mobility, molluscs are particularly suitable for the reconstruction of local features of the environment and their shells are well preserved in sediments of various origins, especially in those with elevated levels of calcium carbonate.

The area of the Podhale basin is composed of Paleogene flysh formations represented by shale and sandstone formations with calcareous cement. In the northern part of the area there is a belt of limestone outcrops belonging to the Pieniny Klippen belt. A considerable content of calcium carbonate in the underlying rocks, and in the mantles of detritus covering them, facilitate the preservation of prolific mollusc assemblages, of varying richness. The sub-fossil fauna of snails and bivalves from the Podhale region has been studied since 
the 1930s, with the primary focus on commonly found localities of calcareous tufas (Alexandrowicz, W.P., 1997, 2001, 2003). A detailed analysis of the changes in the natural environment of the Podhale region in the last 15,000 years, based on rich mollusc communities obtained from sediments of various genetic origins, was carried out by Alexandrowicz, W.P., (1997). The results of this reconstruction correspond well with the conclusions drawn from the studies of peat-bogs in the Orava and Nowy Targ basins (Koperowa, 1962; Obidowicz, $1990,1995)$. Based on these data, it is possible to distinguish several phases of changes in the environment. The older among them is undoubtedly associated with the changes in climate that occurred several times during the Late Glacial and the Holocene. The youngest phase of environmental transformation spanning the last several hundred years is directly associated with the activities of man; principally with agricultural development which precipitated rapid deforestation. The effects of this process involved a marked reduction in the occurrence of shaded habitats which were replaced by open environments, such as cultivated fields and pastures. This phenomenon led to a very clear restructuring of ecosystems and changes in the composition and structure of plant and animal communities, including malacocoenoses.

The development of human settlements in the Podhale is well documented. The first phase occurred in the $13^{\text {th }}$ and $14^{\text {th }}$ centuries and was present mainly in the flat and minimally morphologically-diversified northern section around the Orava and Nowy Targ dells. The first massive deforestations are also associated with this period. Along with the increasing size of human populations, deforestation then commenced to affect the southern part (Czepiel, 1999). The Podhale area is currently deforested to a significant degree, and only coniferous forest communities have still endured, exclusively upon steep slopes unsuitable for agricultural use. The deforestation of slopes has been essential in altering geological processes and has led to an evident increase in the quantity of material carried from the slopes down to the river beds. The effect of this process is manifested in intensified accumulations and the emergence of a system of low (1.5-2 m high) terraces composed of river channel gravel facies covered with sands, as commonly found in river valleys. It is only in these sediments where communities of sub-fossil molluscs have remained preserved, thereby providing evidence of anthropogenic transformations resulting from changes in the environment of the Podhale basin.

\section{Material and methods}

The malacological analysis was carried out on material obtained from 17 localities of Late Holocene fluvial sediments (Fig.1, Table 1). Individual samples weighed 2-3 kgs. Laboratory processing of the materials consisted of washing the rocks, removing complete shells and also identifiable shell fragments. A total of 48 samples of mollusc shell fragments were analyzed. Identification of shell material was completed using guides and comparative collections. The number of species and specimens were determined for each sample. The pieces of shells were calculated into whole specimens according to the formula proposed by Alexandrowicz, S.W., (1987). The number of species at individual localities ranged from 3 to 21 , while the number of specimens ranged from 7 to 173 (Table 1). The analyzed material contained a total of 2,810 specimens of 46 taxa (43 land snail taxa, 1 of an aquatic snail and 1 bivalve species), and the calcareous plates of slugs were included under the collective name of Limacidae.

The malacological analysis followed standard methods devised by Ložek (1964) and Alexandrowicz, S.W., (1987, 1999). Individual species were allocated to ecological groups of species: F - shade-loving, O - open environments, $\mathrm{M}$ - mesophilous, $\mathrm{H}$ - hygrophilous, and $\mathrm{W}$ - aquatic species. Ratios of ecological groups were used to 
construct a triangular diagram and to distinguish four types of faunistic assemblages. TDA, SWN, SMI, and J indices of diversity were calculated to characterize the degree of fauna diversification. These indices were based of the mathematical formulas of Simpson, (1949); Shannon, Weaver, (1949); Pielou, (1975) and Alexandrowicz, S.W., (1987, 1999); and the ADI index characterized the entire collected material (Alexandrowicz, S.W., 1987). The taxonomical analysis enabled determination of similarities between analyzed samples and indicated sample groups of molluscan assemblages with similar composition and structure. Cluster diagram construction followed the method of Morisita (1959) and Wolda (1981), and the PAST statistical software package was used for statistical calculations (Hammer et al., 2001). The constancy structure (C) and the domination structure (D) were characterized for all the analyzed material. These structures permitted the selection of the most typical components of all particular assemblages (Alexandrowicz, S.W., 1987, 1999). Indication of the dominant and accessory species in the collected material was based on the Q index, from the geometric mean of C and D (Alexandrowicz, S.W., 1999). The reconstruction of anthropomorphic changes in the Podhale basin in the last few hundred years was based on this methodology. This was then compared with the results of studies carried out in the peat bogs in the Orava and Nowy Targ basins, and also with results of malacological analyses of sediments of similar origin and age found in the Pieniny and Western Beskidy Mountains.

T a b l e 1. Profiles, samples and diversity indices.

\begin{tabular}{|c|c|c|c|c|c|c|c|}
\hline PT- & Pt- & $\mathbf{N}_{\mathrm{T}}$ & $\mathbf{N}_{\mathrm{S}}$ & TDA & SWN & SMI & $\mathbf{J}$ \\
\hline \multirow{5}{*}{ I } & 1 & 9 & 34 & 0.74 & 1.91 & 0.83 & 0.92 \\
\hline & 2 & 13 & 30 & 0.79 & 2.31 & 0.83 & 0.9 \\
\hline & 3 & 14 & 144 & 0.64 & 1.86 & 0.77 & 0.71 \\
\hline & 4 & 12 & 124 & 0.53 & 1.67 & 0.73 & 0.67 \\
\hline & 5 & 9 & 36 & 0.64 & 1.79 & 0.79 & 0.81 \\
\hline \multirow{3}{*}{ II } & 6 & 3 & 12 & 0.38 & 0.89 & 0.54 & 0.81 \\
\hline & 7 & 4 & 22 & 0.58 & 1.34 & 0.71 & 0.97 \\
\hline & 8 & 4 & 10 & 0.53 & 1.22 & 0.66 & 0.88 \\
\hline \multirow{3}{*}{ III } & 9 & 6 & 10 & 0.69 & 1.61 & 0.76 & 0.9 \\
\hline & 10 & 4 & 17 & 0.21 & 0.65 & 0.31 & 0.48 \\
\hline & 11 & 3 & 7 & 0.45 & 0.96 & 0.57 & 0.87 \\
\hline \multirow{4}{*}{ IV } & 12 & 4 & 20 & 0.41 & 1.07 & 0.59 & 0.77 \\
\hline & 13 & 3 & 7 & 0.45 & 0.96 & 0.57 & 0.87 \\
\hline & 14 & 4 & 10 & 0.58 & 1.28 & 0.7 & 0.92 \\
\hline & 15 & 2 & 25 & 0.26 & 0.59 & 0.4 & 0.85 \\
\hline \multirow{2}{*}{ V } & 16 & 8 & 12 & 0.79 & 1.91 & 0.82 & 0.92 \\
\hline & 17 & 6 & 13 & 0.64 & 1.57 & 0.76 & 0.88 \\
\hline \multirow{3}{*}{ VI } & 18 & 5 & 59 & 0.54 & 1.41 & 0.73 & 0.89 \\
\hline & 19 & 9 & 105 & 0.72 & 2.04 & 0.85 & 0.93 \\
\hline & 20 & 18 & 173 & 0.83 & 2.63 & 0.92 & 0.91 \\
\hline \multirow{3}{*}{ VII } & 21 & 9 & 27 & 0.39 & 1.36 & 0.58 & 0.65 \\
\hline & 22 & 10 & 69 & 0.66 & 1.91 & 0.81 & 0.83 \\
\hline & 23 & 15 & 74 & 0.6 & 1.98 & 0.77 & 0.73 \\
\hline \multirow{2}{*}{ VIII } & 24 & 21 & 115 & 0.85 & 2.75 & 0.92 & 0.9 \\
\hline & 25 & 19 & 148 & 0.81 & 2.6 & 0.91 & 0.88 \\
\hline
\end{tabular}

\begin{tabular}{|c|c|c|c|c|c|c|c|}
\hline PT- & Pt- & $\mathbf{N}_{\mathrm{T}}$ & $\mathbf{N}_{\mathrm{s}}$ & TDA & SWN & SMI & $\mathbf{J}$ \\
\hline \multirow{3}{*}{ IX } & 26 & 8 & 59 & 0.58 & 1.67 & 0.76 & 0.8 \\
\hline & 27 & 6 & 38 & 0.45 & 1.34 & 0.64 & 0.75 \\
\hline & 28 & 11 & 59 & 0.69 & 2.04 & 0.83 & 0.85 \\
\hline \multirow{3}{*}{$\mathbf{X}$} & 29 & 6 & 66 & 0.52 & 1.44 & 0.71 & 0.8 \\
\hline & 30 & 9 & 97 & 0.72 & 2.07 & 0.85 & 0.94 \\
\hline & 31 & 18 & 122 & 0.81 & 2.48 & 0.9 & 0.86 \\
\hline \multirow{3}{*}{ XI } & 32 & 11 & 108 & 0.74 & 2.14 & 0.62 & 0.89 \\
\hline & 33 & 14 & 95 & 0.81 & 2.46 & 0.91 & 0.93 \\
\hline & 34 & 8 & 95 & 0.64 & 1.78 & 0.8 & 0.86 \\
\hline \multirow{3}{*}{ XII } & 35 & 5 & 52 & 0.58 & 1.49 & 0.76 & 0.92 \\
\hline & 36 & 4 & 31 & 0.45 & 1.99 & 0.65 & 0.86 \\
\hline & 37 & 5 & 26 & 0.56 & 1.41 & 0.83 & 0.88 \\
\hline \multirow{2}{*}{ XIII } & 38 & 12 & 90 & 0.57 & 1.81 & 0.76 & 0.73 \\
\hline & 39 & 17 & 75 & 0.69 & 2 & 0.83 & 0.78 \\
\hline \multirow{3}{*}{ XIV } & 40 & 16 & 148 & 0.7 & 2.19 & 0.85 & 0.79 \\
\hline & 41 & 11 & 80 & 0.6 & 1.85 & 0.77 & 0.77 \\
\hline & 42 & 19 & 102 & 0.66 & 2.19 & 0.81 & 0.74 \\
\hline \multirow{2}{*}{ XV } & 43 & 5 & 10 & 0.56 & 1.36 & 0.68 & 0.84 \\
\hline & 44 & 5 & 19 & 0.57 & 1.41 & 0.72 & 0.88 \\
\hline \multirow{2}{*}{ XVI } & 45 & 3 & 11 & 0.4 & 0.92 & 0.56 & 0.83 \\
\hline & 46 & 6 & 36 & 0.63 & 1.64 & 0.78 & 0.92 \\
\hline \multirow{2}{*}{ XVII } & 47 & 8 & 33 & 0.52 & 1.63 & 0.7 & 0.78 \\
\hline & 48 & 9 & 59 & 0.6 & 1.7 & 0.77 & 0.77 \\
\hline
\end{tabular}

Notes: PT - profiles, Pt - samples, $\mathrm{N}_{\mathrm{T}}$ - number of taxa, $\mathrm{N}_{\mathrm{S}}$ - number of specimens, TDA - antilogarithm of Taxonomical Diversity Index, SWN — Shannon-Weaver Index, SMI — Simpson Index, J — Pileou Index. 


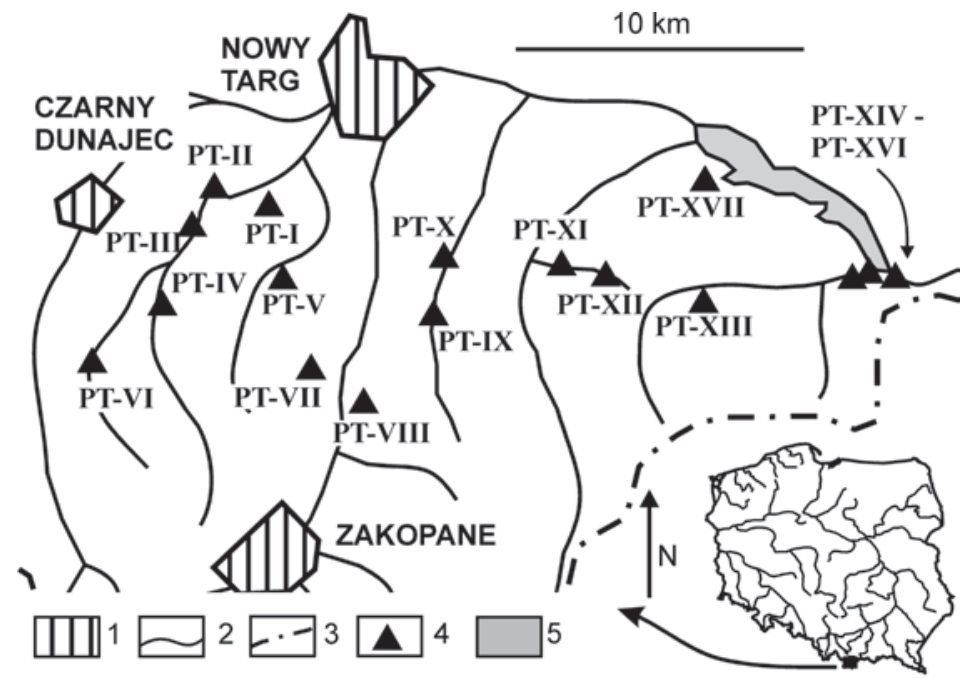

Fig. 1. Localization of sites Late Holocene fluvial deposits with malacofauna in Podhale basin.

1 - towns, 2 - rivers, 3 - national border, 4 - analyzed profiles, 5 - Czorsztyn Dammed lake, I-XVI - profiles described in text.

\section{Results}

The studies of malacological fauna were carried out on 17 profiles of fluvial sediments in the Podhale area (Fig. 1). These localities represent two principal types of river valleys. The first includes the wide, flat-bottomed valleys, characterized by the presence of broad terrace steps, now mostly deforested and under cultivation. The terraces had marked similarities throughout the study area, and numerous undercuts exposed the profiles of fluvial sediments composed of two elements. The lower one consisted of fine to medium-grained gravels with an abundant sand matrix, and their petrographic composition depended closely on the geological structure of the stream drainage area. The gravels are covered by sandy-dusty fen soils whose thickness ranges from 0.5 to $1.0 \mathrm{~m}$. This type is present in the following localities; Rogoźnik stream (profiles PT-I - PT-IV), in Trybsz (profiles PT-XI and PT-XII), in Łapsze Wyżne (profile PT-XIII), in Niedzica (profiles PT-XIV - PT-XVI) and in Frydman (profile PT-XVII) (Fig. 1).

The second element is represented by narrow, deeply-cut, ravined sections of small streams, or narrow ravined sections of larger rivers. Here the youngest terrace systems form narrow, often discontinuous strips, whose height is usually less than $0.5 \mathrm{~m}$ above of the present river bed. These terraces comprise gravels with variable-size cobbles sometimes covered by sandy fen soils less than $0.2 \mathrm{~m}$ thick, and are present in the following localities: Maruszyna (profile PT-V), Dzianisz (profile PT-VI), Skrzypne (profile PT-VII), Gliczarów (profile PT-VIII), and Leśnica (profiles PT-IX and Pt-X), (Fig. 1).

The molluscan assemblage recognized in the Late Holocene fluvial sediments in the Podhale basin is relatively sparse and includes a total of 46 taxa. This is approximately $50 \%$ of all species currently living in this area (Riedel, 1988). 
The constancy and domination indices were calculated for the entire fauna in order to characterize the structure of the assemblages and to indicate dominant and accessory species (Fig. 2). The most characteristic species is the Vallonia pulchella (Müll.), with high constancy (class $C=5$ ) and domination $(D=5)$. This means that the taxon appears in more than $80 \%$ of samples and represents more than $20 \%$ of the entire analyzed shell material (Fig. 2). The high classes of constancy and domination include; Cochlicopa lubrica (Müll.), Perforatella vicina (Rossm.), Vallonia costata (Müll.), Nesovitrea hammonis (Strom) and Limacidae. These six taxa comprise the most characteristic components of assemblages in the Late Holocene fluvial sediments in the Podhale basin. The remaining 40 taxa have low CD values (classes 1 and 2) and are supplementary and accessory elements (Fig. 2). The Q index allows estimation of the significance of individual species in the analyzed malacofauna.. Its high values are typical of forms that commonly occur in high numbers. Low values characterize species that occur only very rarely. Taxa with great constancy and marked domination have the highest $\mathrm{Q}$ values, and in addition to the six species mentioned, 6 more species can be included in this group $(\mathrm{Q}>8$ ) (Table 2). Species with $\mathrm{Q}$ values in the $\operatorname{range} \mathrm{Q}=8$ to $\mathrm{Q}=2$ are supplementary elements of significance in palaeo-interpretation of mollusc assemblages (16 species). The remaining 18 taxa with Q values of less than 2 are accessory elements of minor significance (Table 2).

\begin{tabular}{|c|c|c|c|c|c|}
\hline $\mathrm{C}$ & 1 & 2 & 3 & 4 & 5 \\
\hline 5 & & & & 1 & 1 \\
\hline 4 & & & & & \\
\hline 3 & & 2 & 1 & 1 & \\
\hline 2 & 3 & 9 & & & \\
\hline 1 & 23 & 5 & & & \\
$D$ & $=5 ; C=5$ Vallonia pulchella \\
$D$ & $=4 ; C=5$ Cochlicopa lubrica \\
$D$ & $=4 ; C=3$ Perforatella vicina \\
$D$ & $=3 ; C=3$ Vallonia costata \\
$D$ & $=2 ; C=3$ Nesovitera hammonis & Limacidae
\end{tabular}

Fig. 2. Structure of constancy (C) and domination (D) of Late Holocene fluvial deposits in Podhale basin.

The indices of diversity of assemblages (TDA, SWN, SMI) and homogeneity index (J), are indicative of relatively high differences in the composition in structure of molluscan assemblages recognizable in individual samples. The index values are compiled in Table 1 and the ratios between them are depicted in Fig. 3. Indices TDA and SWN and also SWN and SMI, show clear correlations, with respective values of the linear correlation coefficients of $r=0.90$ and $r=0.86$, (Figs. $3 \mathrm{~A}, \mathrm{~B}$ ). This indicates the possibility of the interchangeable use of these indices in characterizing malacofauna assemblages. Here, the correlation between SWN and $\mathrm{J}$ indices was very weak at $\mathrm{r}=0.27$, (Fig. 3C). When the values of the J index were juxtaposed with the numbers of taxa, it was possible to distinguish four sample groups. The first group (I) includes samples with the highest numbers of taxa; exceeding 15. The second group (II) includes moderately diversified assemblages with their taxa numbers ranging from 5 to 15 , while the third group (III) includes those associations with low numbers of species. A single sample with enormous predominance of one species was set apart as the fourth group (IV) (Fig. 3D). 
T a b l e 2. Malacafauna of Late Holocene fluvial deposits in Podhale basin.

\begin{tabular}{|c|c|c|c|}
\hline $\mathrm{CD}(\mathrm{D} \geq 5 \% ; \mathrm{C} \geq 50 \%)$ & Q & $\mathrm{Cd}(\mathrm{D}<5 \% ; \mathrm{C} \geq 50 \%)$ & Q \\
\hline $\begin{array}{l}\text { Vallonia pulchella } \\
\text { Cochlicopa lubrica } \\
\text { Perforatella vicina } \\
\text { Vallonia costata }\end{array}$ & $\begin{array}{l}43.05 \\
29.42 \\
26.04 \\
22.24\end{array}$ & & \\
\hline $\mathrm{cD}(\mathrm{D} \geq 5 \% ; \mathrm{C}<50 \%)$ & Q & cd $(D<5 \% ; C<50 \%$ & Q \\
\hline & & $\begin{array}{l}\text { Nesovitrea hammonis } \\
\text { Vitrea crystallina } \\
\text { Perforatella incarnata } \\
\text { Punctum pygmaeum } \\
\text { Limacidae } \\
\text { Pupilla muscorum } \\
\text { Vitrina pellucida } \\
\text { Bradybaena fruticum } \\
\text { Carychium minimum } \\
\text { Vertigo pygmaea } \\
\text { Succinea putris } \\
\text { Macrogastra ventricosa } \\
\text { Galba truncatula } \\
\text { Aegopinella pura } \\
\text { Succinea oblonga } \\
\text { Perforatella umbrosa } \\
\text { Carychium tridentatum } \\
\text { Arianta arbustorum } \\
\text { Vitrea diaphana } \\
\text { Isognomostoma isognomostoma } \\
\text { Pisidium personatum } \\
\text { Vertigo pusilla } \\
\text { Macrogastra tumida } \\
\text { Euconulus fulvus } \\
+18 \text { species (Q<2) }\end{array}$ & $\begin{array}{c}13.44 \\
12.75 \\
12.35 \\
9.98 \\
9.84 \\
9.55 \\
9.31 \\
8.47 \\
6.83 \\
6.02 \\
5.38 \\
5.02 \\
4.90 \\
4.66 \\
4.39 \\
4.21 \\
4.19 \\
3.84 \\
3.14 \\
3.08 \\
2.94 \\
2.81 \\
2.48 \\
2.43\end{array}$ \\
\hline
\end{tabular}

Notes: C - constancy, D - domination, Q - the geometric mean of C and D.

Compiling the values of the TDA index calculated for individual samples vis-à-vis the numbers of taxa in these samples enables the possibility of distinguishing three types of associations (Fig. 4).

The first type (A type) includes oligomictic assemblages with few components, which are characterized by a small number of taxa and low TDA values. This type encompasses associations with a high frequency of some single species and with a low proportion of other molluscs. This type is represented by 10 samples which constitute $21 \%$ of the entire material collected.

The second type contains polymictic assemblages with several components (type C), showing high TDA values (TDA > 0.5) but with little diversified species composition. These associations are poor in terms of both individuals and taxa numbers. This group encompasses chiefly mixed assemblages without any clear dominant components. Associations with such features were found in 22 samples ( $46 \%$ of the material analyzed). The third and last type encompasses associations with both high species diversity and high numbers of specimens (polymictic, multi-component assemblages - type D). This group mainly includes 

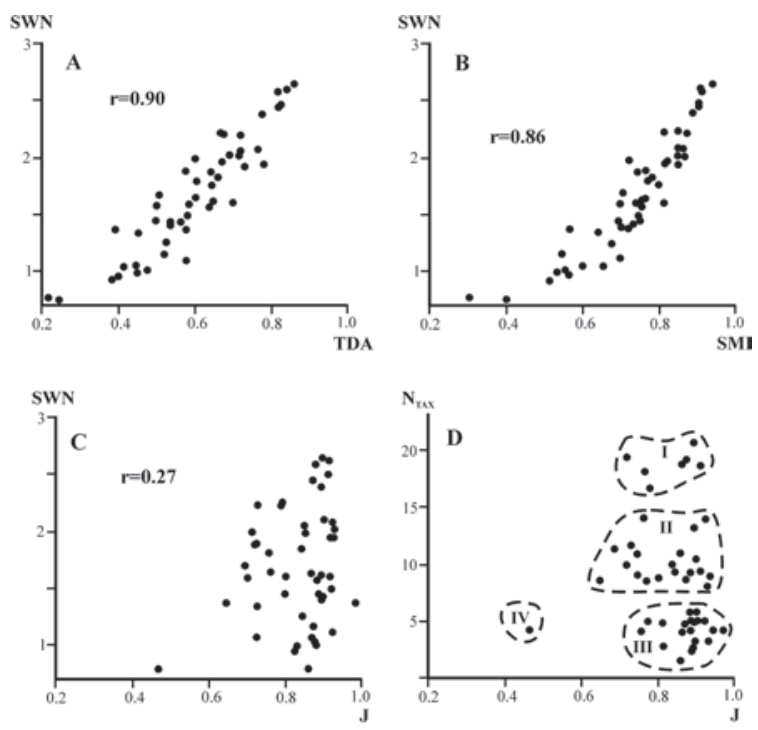

Fig. 3. Diagrams of differentiation indices.

A - Shannon-Weaver (SWN) versus antilogarithm of Taxonomical Diversity Index (TDA), B - Shannon-Weaver (SWN) versus Simpson (SMI), C - Shannon-Weaver (SWN) versus Pileou (J), D - Pileou (J) versus number of $\operatorname{taxa}\left(\mathrm{N}_{\mathrm{TAX}}\right)$.

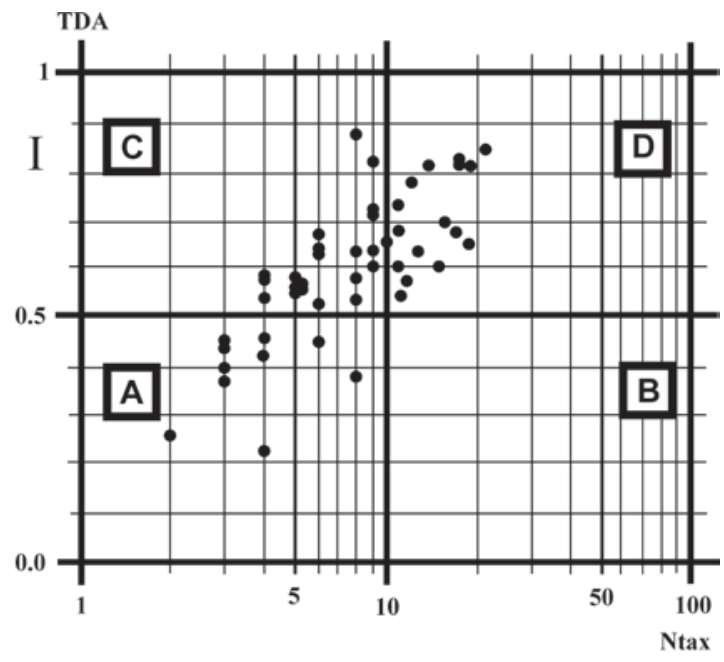

Fig. 4. Differentiation of molluscan assemblages of Late Holocene fluvial deposits in Podhale basin.

Types of assemblages: 1 - oligomictic, less diversity assemblages (A), 2 - oligomictic multiple assemblages (B), 3 - polimictic, less diversity assemblages (C), 4 - polimictic multiple assemblages (D), TDA - antilogarithm of Taxonomical Diversity Index, $\mathrm{N}_{\operatorname{tax}}-$ number of taxa. 
fauna with a predomination of shade-loving and mesophilic species. The values of the TDA index are often markedly above 0.5 . Associations with these characteristics were found in 16 samples, which comprised $33 \%$ of the material studied.

The high value of the ADI index of 0.824 calculated for the entire collected material indicates the significant degree of diversification of the fauna analyzed.

\section{Discussion}

The palaeo-ecological structure of malacofauna in individual samples displayed considerable differences. The principal differentiating factor is the variable proportions of the forms typical of open environments and those living in shaded habitats. This kind of differentiation allows separation of two principal types of fauna assemblages. The first includes associations with a small proportion of shade-loving snails reaching a maximum level of $20 \%$ of the association. The second type has a low, below $30 \%$, frequency of taxa typical for open environments (Fig. 5). A more detailed analysis enables them to be divided into subtypes (Figs 5, 6).

Within the assemblage with a high proportion of species preferring shaded habitats (AS - I), it was possible to distinguish the following types of fauna:

- F-type fauna - a rich association with high species diversity and definite domination of shade-loving snails, often enhanced by a significant portion of forest species which prefer habitats with elevated humidity. Here, mesophilous snails are a supplementary

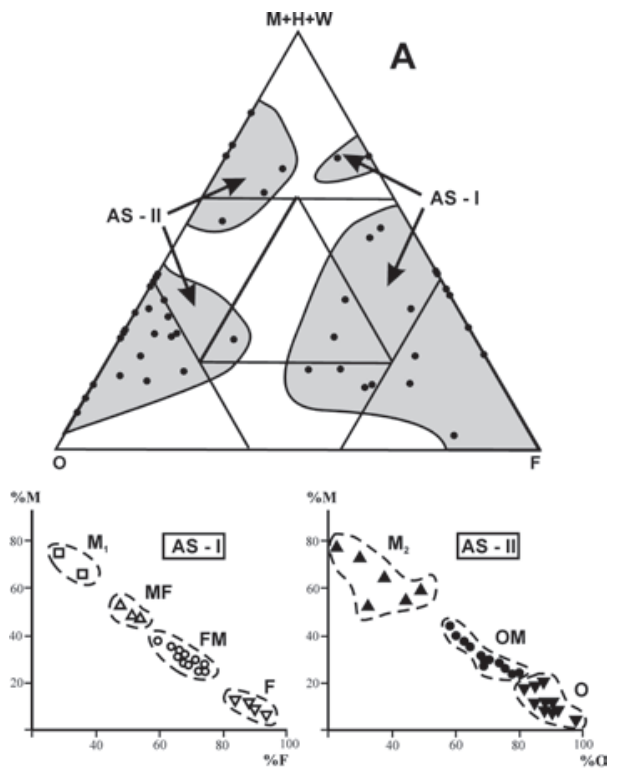

Fig. 5. Molluscan assemblages of Late Holocene fluvial deposits in Podhale basin.

Ecological groups of molluscs (based on Ložek, 1964; Alexandrowicz, S.W., 1987, 1999): W — water species, H — hygrophilous species, $\mathrm{M}$ - mesophilous species, $\mathrm{O}$ - meadow species, $\mathrm{F}$ - shade-loving species, $\mathrm{A}-$ triangular diagram, AS-I, AS-II - types of molluscan assemblages described in text. Symbols of communities are described 


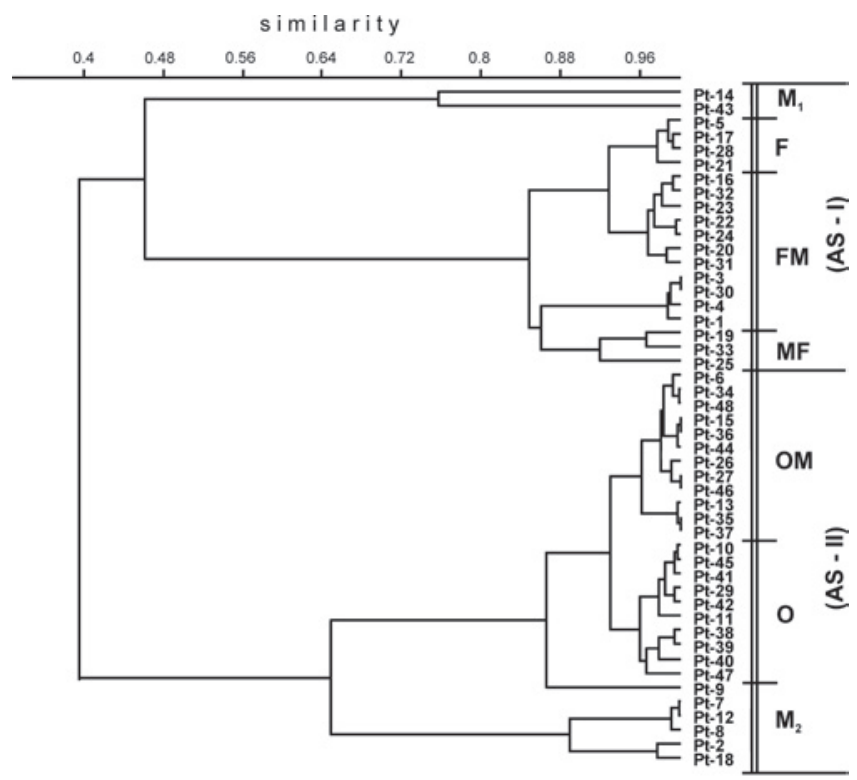

Fig. 6. Cluster diagram of malacofauna from Late Holocene fluvial deposits in Podhale basin. Pt-1-Pt-48 - analyzed samples (see also in Table 1). AS-I, AS-II - types of molluscan assemblages described in text. Symbols of communities are described in text.

element. Taxa preferring open environments are very rare or absent, and this type of assemblage was found in only 4 samples; or $8 \%$ of the material studied (Figs 5, 6).

- FM-type fauna - is similar to the F-type, with the main difference being the higher proportion of mesophilous species, usually comprising 25 to $40 \%$ of the association. The proportion of shade-loving element ranges from 50 to $70 \%$ of the association. The remaining ecological groups are of secondary and accessory, significance. The above-mentioned association occurred in 11 samples; or 23\% of analyzed fauna) (Figs 5, 6).

- MF-type fauna - this malacocoenosis is characterized by a quite high proportion of mesophilous species (45-60\%). Shade-loving snails, represented by the taxa of humid habitats are the second most important component found in this association. Meadow and hygrophilous forms occur rarely, with this type found in only 3 samples; or $7 \%$ of the collected material (Figs 5, 6).

- $\mathrm{M}_{1}$-type fauna - is an association poor in terms of the number of species, with little diversification, and dominated by mesophilous species which constitute up to $80 \%$ of the assemblage. Shade-loving forms are merely supplementary. M1 Fauna was found in only 2 samples; or $4 \%$ of the material analyzed (Figs 5,6 ).

The association dominated by species of open environments (AS - II) can be divided into three sub-associations:

- O-type fauna - is an association poor in terms of species number, and it also has low diversification usually composed of a few species. The dominant element comprises meadow snails typical of dry or moderately humid habitats. Here, mesophilous forms 
constitute an admixture, and shade-loving species occur sporadically. The proportion of snails inhabiting open environments exceeds $80 \%$. This association was found in 10 samples; or $22 \%$ of the fauna (Figs 5,6 ).

- OM-type fauna - is the association most often encountered (12 samples - $25 \%$ of the association). Their most important element comprises open-country taxa supplemented by mesophilous forms and a small number of species preferring more shaded habitats. Hygrophilous snails sometimes occur, while aquatic species are sporadic (Figs $5,6)$.

- $\mathrm{M}_{2}$-type fauna - is a malacocoenosis with a high percentage of mesopholius snails associated with relatively dry habitats. The meadow forms are supplementary although their proportion is usually less than $40 \%$. Molluscs preferring shaded habitats and hygrophilous species both occur only sporadically. The fauna was found in 6 samples; or $13 \%$ of the material analyzed (Figs 5, 6).

On the basis of separated and defined associations, it was possible to determine the sequence of particular types of fauna appearing in the studied profiles. The sequences of the associations are indicators of changes in the environment which reflect the impact of human activities in the Podhale region. Undoubtedly, natural factors, chiefly climatic ones, have also affected the composition and structure of malacocoenoses. It should be noted, however that even the major cooling of the climate associated with the Little Ice Age was too short to result in a significant change in the composition of the fauna. Hence, the changes in the features of mollusc associations of the Podhale basin fluvial sediments can be interpreted as the results of human activity. It is possible to distinguish three types of succession. Each is associated with a particular type of river valley.

$\mathrm{O}$ - O-type succession - this is a characteristic sequence showing little variability in the composition and structure of malacofauna found in the samples. The most essential role in the entire sequence is played by malacofauna which are scarce in terms of individual species numbers, but high proportions of different species are found in open environments. This is a sequence typical of wide valleys with gently inclined slopes which were deforested first and then converted to suit pastoral or farming purposes because of their typographical relief. The sediments which formed the profiles with such sequences were thus formed in the period of intensified human impact and settlement activity. This type is the most numerous and it was found in the following profiles: PT-II - PT-IV (Rogoźnik stream valley), PT-XII (Trybsz), PT-XIII (Łapsze), PT-XIV - PT-XVI (Niedzica) and PT-XVII (Frydman).

$\mathrm{F}$ - F-type succession - is a sequence typical of narrow river valleys usually in the form of deep V-shaped valleys. The malacofauna is usually rich and its species composition is quite varied. There is a marked predominance of species in more or less shaded habitats, often in increased humidity. There are also numerous mesophilous taxa, but a low proportion of snails inhabiting open environments. This sequence is characteristic of areas not utilized by humans, chiefly because of the adverse relief features, such as steep valley slopes. In several profiles, traces of deforestation are clearly emphasized by the appearance of associations with higher proportions of mesophilous species, or even meadow species. The presented sequence was identified in 5 profiles: PT-I (a tributary of the Rogoźnik stream), PT-V (Maruszyna), PT-VI (Dzianisz), PT-VII (Skrzypne) and PT-VIII (Gliczarowski Potok). 
F - O-type succession sequence was found in three profiles: PT-IX, PT-X (Leśnica), and PT-XI (Trybsz). Shade-loving species dominated the inferior part, while meadow species thrived in the upper domains. The rapid and evident change in habitat nature indicates sudden deforestation which is undoubtedly associated with human activity. Both these profiles are situated in a relatively narrow valley which was only later subject to intensive human activity.

\section{Conclusion}

The evolution of the natural environment of the Podhale basin is relatively well documented. This knowledge was accumulated owing to a number of studies of palynological profiles of several peat bogs in the Orava region and around the Nowy Targ area (Koperowa, 1962; Obidowicz, 1990, 1995), plus research on mollusc associations occurring in sediments of different origins, particularly in calcareous tufas (Alexandrowicz, W.P., 1997, 2001, 2003, 2010). Besides floristic and faunistic documentation, radiocarbon dating was also performed in a number of the profiles. These data enable the conclusion to be drawn that there was an expansion of forests in the area of the Podhale basin at the beginning of the Holocene. The forest environments have been sustained since historic times, and the evident transformation of habitat types is clearly marked in the peat-bog profiles, underscored by a rapid increase in the pollen content of herbaceous plants coupled with a simultaneous drop in the frequencies of tree pollen. The period of these changes dates from the $13^{\text {th }}$ and $14^{\text {th }}$ centuries (Ralska-Jasiewiczowa, 1988; Czepiel, 1999). This period is associated with a rapid growth in the human population. This process in turn led to the necessity to acquire new land for cultivation which entailed intensified deforestation. The associations of molluscs found in the above-mentioned fluvial sediments record this particular process. Material collected and analyzed indicates a high diversity of habitats and variable rate of anthropogenic changes. The first phase of deforestation involved the northern part of the Podhale basin, characterized by gentle relief, and presence of wide valleys with well-developed systems of flat extensive terraces. This phase is linked with the period from the $13^{\text {th }}-15^{\text {th }}$ centuries when a rapid development of villages occurred in this area (Ralska-Jasiewiczowa, 1988; Czepiel, 1999). The significant reduction in forested areas resulted in changes in malacocoenoses. The rich associations with high proportions of forest species, dominating in the period preceding the settlement drive, were replaced by the poorer and more narrowly diversified associations, dominated by forms typical of open habitats. Deforestation did not affect those areas with relief unsuitable for farming, such as in the deep and narrow valleys. In these zones, malacocoenoses with high proportions of shade-loving species maintained their presence. Similar diversification is also observed in recent times. In some profiles, particularly in their canopy sections, a periodic increase in the proportion of shade-loving and mesophilous species is marked, coupled with a reduced frequency in the occurrence of the meadow element.

On the basis of changes in the composition of molluscan fauna occurring in fluvial sediments, the following stages of the environmental changes can be distinguished (Fig. 7, Table 3):

Stage I - spans the period from the beginning of the Holocene until the Middle Ages. This phase was dominated by forest environments. In various localities with sediments of gene- 
tically different lithological types, rich and diversified associations of molluscs were found, dominated by shade-loving and mesophilous species with smaller or larger admixtures of aquatic and hygrophilous forms. This period preceded colonization of the Podhale Basin by humans, and small human communities present in the area did not unduly affect the natural environment in any significant way (Alexandrowicz, W.P., 1997, 2001, 2003; Alexandrowicz, W.P., Stworzewicz, 2003) (Fig. 7 , Table 3).

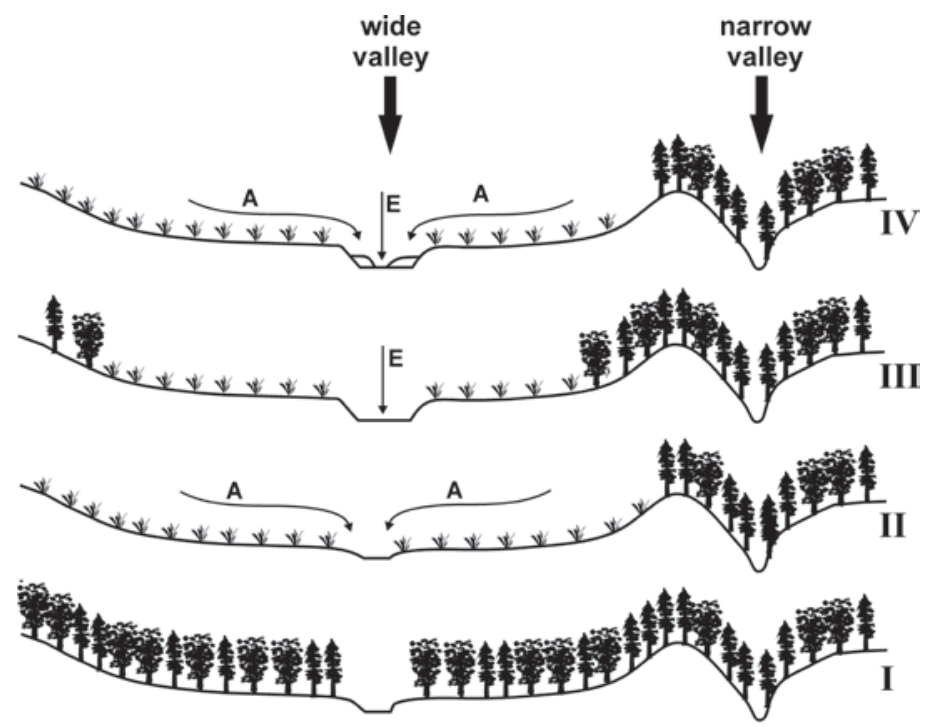

Fig. 7. Phases of environmental changes of Podhale basin during the last Millennium.

$\mathrm{E}$ - erosion, A - accumulation, I-IV - phases of environment development described in text.

$\mathrm{T}$ a b l e 3. Phases of environment development and human impact in Podhale basin.

\begin{tabular}{|c|c|c|c|c|c|c|}
\hline Period & Phase & Climate & River activity & Human population & $\begin{array}{c}\text { Anthropogenic } \\
\text { pressure }\end{array}$ & Forests \\
\hline $\begin{array}{l}\text { Holocene } \\
\text { untill 13th } \\
\text { century }\end{array}$ & I & variable & veriable & $\begin{array}{l}\text { small human } \\
\text { population }\end{array}$ & unimportant & $\begin{array}{l}\text { development } \\
\text { of forests }\end{array}$ \\
\hline $\begin{array}{l}\text { Mediaeval } \\
\text { Warm Period }\end{array}$ & II & warm & $\begin{array}{l}\text { mainly } \\
\text { accumulation }\end{array}$ & $\begin{array}{l}\text { colonization, fast } \\
\text { growing of human } \\
\text { population }\end{array}$ & locally strong & $\begin{array}{l}\text { deforestation main- } \\
\text { ly in wide valleys } \\
\text { and } \\
\text { gentle slopes }\end{array}$ \\
\hline Little Ice Age & III & cold & erosion & $\begin{array}{l}\text { small reduction } \\
\text { of human popula- } \\
\text { tion }\end{array}$ & locally strong & locally afforestation \\
\hline $\begin{array}{l}\text { Last two } \\
\text { centuries }\end{array}$ & IV & recent & $\begin{array}{l}\text { erosion and } \\
\text { accumulation }\end{array}$ & $\begin{array}{l}\text { fast growing of } \\
\text { human population }\end{array}$ & $\begin{array}{l}\text { strong in } \\
\text { whole area }\end{array}$ & $\begin{array}{l}\text { strong } \\
\text { deforestation } \\
\text { except narrow } \\
\text { valleys and steep } \\
\text { slopes }\end{array}$ \\
\hline
\end{tabular}


Stage II - the $13^{\text {th }}-15^{\text {th }}$ centuries. The intensified settlement activity which began in the $13^{\text {th }}$ century resulted in significant deforestation, especially in the northern part of the Podhale (Koperowa, 1962; Obidowicz, 1990, 1995; Alexandrowicz, W.P., 1997). The effects of this process included, on the one hand, intensified fluvial accumulation, and, on the other, a significant change in composition and structure of malacocenoses. Associations previously dominated by forest species were replaced by poorer faunas, with the majority being forms in open environments together with an admixture of mesophilous snail species. The occurrence of fluvial sediments described in this study is associated with this phase. These changes are, in turn, associated with the phase when the climate warmed considerably in the Medieval Warm Period (Grove, Switsur, 1994; Huges, Diaz, 1994; Bradley, 2000; Briffa, 2000; Jones, Mann, 2004) (Fig. 7, Table 3).

Stage III $-14^{\text {th }}-19^{\text {th }}$ centuries. The cooling of the climate associated with the Little Ice Age (Bradley, Jones, 1993; Bradley, 2000; Briffa, 2000; Jones, Mann, 2004) led to a reduction in the human population, lessening human impact and consequently an expansion in forests. This process manifested itself by the increased proportion of shade-loving forms noted in particular profiles. Intensified fluvial activity in this period (Ralska-Jasiewiczowa, Starkel, 1988; Starkel et al., 1996) caused increased fluvial erosion which consequently led to a decrease in previously accumulated fluvial sediments (Fig. 7, Table 3).

Stage IV $-20^{\text {th }}$ century. This period involved the rapid expansion of settlements and progressive deforestation. In river valleys, this period corresponds to the lowest and youngest terrace system, composed mainly of gravels and devoid of fragments of molluscan shells (Fig. 7, Table 3).

In the Podhale basin area there are also other sediments, representing a similar period of time and containing numerous mollusc shells. These are recently precipitated calcareous tufas and also sediments accumulated in small karst forms on limestone rocks in the Pieniny Klippen belt (Alexandrowicz, W.P., 1997, 2010; Alexandrowicz, W.P., Rudzka, 2006). Rich associations with significant proportions of forest and mesophilous species were found in the calcareous tufas, while forms typical of open environments were very rare. The faunistic assemblage sequences do not depict phases of human impact-related periods of deforestation in the Podhale region. This may be linked to the fact that calcareous tufas are formed in the spring zones of streams unsuitable for agricultural development. The fauna of the calcareous tufas shows certain similarities, both in terms of species composition and structure of mollusc assemblages to the associations found in the profiles of fluvial sediments deposited in narrow valleys. However, essential differences exist, and the most important of these is the presence of numerous shells of aquatic snails and bivalves within the tufa sediments. These forms are particularly characteristic of springs and do not occur in fluvial sediments (Alexandrowicz, W.P., 1997, 2010). The Early-Holocene malacocoenoses associated with limestone klippes characterize open environments, and sometimes even xerothermic ones. However, they have a specific species composition, closely associated with local habitats, with quite significant and even dominant proportions of petrophilous forms. These sequences do not correspond with anthropogenic transformations of the environment within the Podhale basin in the period concerned (Alexandrowicz, W.P., 1997; Alexandrowicz, W.P., Rudzka, 2006). 
Mollusc associations very similar to those described in this study were reported from the Pieniny area (Alexandrowicz, S.W., 1990, 1993). Two types of fauna were found in a number of profiles of the Late Holocene fluvial deposits. The older one shows the dominance of shade-loving species and it is associated with the early Medieval period (radio carbonda-

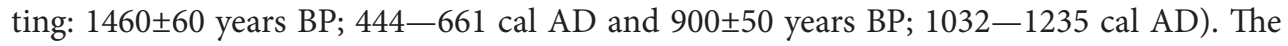
younger malacocoenoses are mainly composed of species from open environments, and in the Podhale basin, these are associated in a similar manner to the last 500 years and they are indicative of anthropogenic deforestation. Similar faunistic sequences, representing a similar period, were described in the area of the Flysh Carpathians. The anthropogenic deforestations occurring in Medieval times were also quite marked in the inner mountain basins and in the Carpathian foreland (Alexandrowicz, S.W., 1984; Alexandrowicz, S.W., Alexandrowicz, W.P., 1995). Such rapid changes in types of habitats associated with the development of farming were also described in other Central and Western European countries. Nevertheless, it should be noted that, depending on the region, these were associated with various phases of human population expansion, beginning in the Neolithic age and lasting until recent times (Rousseau et al., 1992; Kiss et al., 2004; Mishra et al., 2007; Laurent et al., 2008; Frenzel, 2009, and many others).

It is quite clear from the above-mentioned facts that the malacofauna occurring in the fluvial sediments is one of the best indicators of rapid and sudden changes in the environment associated with human activity. This particularly applies to the processes of deforestation and the development of land cultivation and pastoral management.

Acknowledgements

Translated by the author

English corrected by R. Marshall

This study was sponsored by AGH University of Science and Technology through University grant No. 11.11.140.173.

\section{References}

Alexandrowicz, S.W. (1984). Malacofaunal assemblages in the Quaternary deposits of the Polish Carpathians (in Polish). Biuletyn Instytutu Geologicznego, 346, 187-205.

Alexandrowicz, S.W. (1987). Malacological analysis in Quaternary research (in Polish). Kwartalnik AGH, Geologia, 12(1-2), 3-240.

Alexandrowicz, S.W. (1990). The malacofauna of Late Holocene sediments of Sromowce (the Pieniny Mountains, Southern Poland). Folia Malacologica, 4, 7-24.

Alexandrowicz, S.W. (1993). Late Holocene molluscan assemblages from Czorsztyn (Pieniny Klippen belt, Southern Poland). Folia Malacologica, 5, 15-24.

Alexandrowicz, S.W. (1999). Shell accumulations in fluviatile sedimentary environment - methods and interpretation (in Polish). Kwartalnik AGH, Geologia, 25(3), 211-295.

Alexandrowicz, S.W. \& Alexandrowicz W.P. (1995). Quaternary molluscan assemblages of the Polish Carpathians. Studia Geomorphologica Carpatho-Balcanica, 29, 41-54.

Alexandrowicz, W.P. (1997). Malacofauna of Quaternary deposits and environmental changes of the Podhale basin during the Late Vistulian and Holocene (in Polish). Folia Quaternaria, 68, 7-132.

Alexandrowicz, W.P. (2001). Late Vistulian and Holocene molluscan assemblages from calcareous tufa at Ostrysz hill (Podhale basin). Folia Malacologica, 9(3), 159-169.

Alexandrowicz, W.P. (2003). The exposure of calcareous tufa in Gliczarów in the Podhale basin (in Polish). Chrońmy Przyrodę Ojczystą, 59(3), 17-32.

Alexandrowicz, W.P. (2010). Molluscan assemblages of recent calcareous tufa in Podhale basin and Pieniny Mts (Southern Poland). Folia Malacologica, 18(3), 99-112. DOI:10.2478/v10125-010-0009-9. 
Alexandrowicz, W.P. \& Rudzka D. (2006). Molluscan communities from cave and slope deposits of the liomestone rocky hills in the eastern part of Podhale Basin (Southern Poland). Folia Malacologica, 14(4), 191-201.

Alexandrowicz, W.P. \& Stworzewicz E. (2003). Snails (Gastropoda). In P. Valde-Nowak, A. Nadachowski \& T. Madeyska (Eds.), Obłazowa cave. Human activity, stratigraphy and palaeoenvironment (pp. 91-94). Krakow: Institute of Archaeology and Ethnology PAS.

Bradley R.S. (2000). Past global changes and their significance for the future. Quaternary Science Reviev, 19, 391-402. DOI:10.1016/S0277-3791(99)00071-2.

Bradley, R.S. \& Jones P.D. (1993). ,Little Ice Age' summer temperature variations: their nature and relevance to recent global warming trends. The Holocene, 3, 367-376. DOI:10.1177/095968369300300409.

Briffa, K.R. (2000). Annual climate variability in the Holocene: interpretating the message of ancient trees. Quaternary Science Review, 19, 87-105. DOI:10.1016/S0277-3791(99)00056-6.

Czepiel, J. (1999). History of colonization of Podhale region (in Polish). Kraków: Abrys.

Frenzel, B. (2009). Quaternary palaeoecology: Major palaeontological problems of Europe. Progr. Bot, 70, $241-255$.

Grove, J.M. \& Swistur R. (1994). Glacial geological evidence for the Medieval Warm Period. Clim. Change, 26, 143-169. DOI:10.1007/BF01092411.

Hammer, Ø., Harper, D.A.T. \& Ryan P.D. (2001). Past: paleontological statistics software package for education and data analysis. Palaeontologica Electronica, 4, 1-9.

Hughes, M.K. \& Diaz H.F. (1994). Was there a ,Medieval Warm Period' and if so, when and where? Clim. Change, 26, 109-142. DOI:10.1007/BF01092410.

Jones, P.D. \& Mann M.E. (2004). Climate over past millennia. Reviews of Geophysics, 42, 1-42. DOI:10.1029/2003RG000143.

Kiss, L., Magnin, F. \& Torre F. (2004). The role of landscape history and persistent biogeographical patterns in shaping the responses of Mediterranean land snail communities to recent fire disturbances. J. Biogeogr., 31(1), 145-157. DOI:10.1046/j.0305-0270.2003.01011.x .

Koperowa, W. (1962). The history of Late Glacial and Holocene vegetation in Nowy Targ basin (in Polish). Acta Paleobot., 2(3), 30-75.

Laurent, L., Clet-Pellerin, M., Limondin-Lozouet, N., Pastre, J., Fontugne, M. \& Marcigny C. (2008). Fluvial system evolution and environmental changes during the Holocene in the Mue valley (Western France). Geomorpho$\log y, 98,55-70$.

Ložek, V. (1964). Quartärmollusken der Tschechoslowakei. Rozpravy Ústředního Ústavu Geologického, 31, 1-374.

Mishra, S., White, M.J., Beaumont, P., Antoine, P., Bridgland, D.R., Limondin-Lozouet, N., Stantisteban, J.I., Schreve, D.C., Shaw, A.D., Wenban-Smith, F.F., Westaway, R.W.C. \& White T.S. (2007). Flvial deposits as an archive of early human activity. Quaternary Science Reviews, 26: 2996-3016. DOI:10.1016/j.quascirev.2007.06.035.

Morisita, M. (1959). Measuring of interspecific association and similarity between communities. Memoris of the Faculty of Sciences, Kyushu University, E, 3, 65-80.

Obidowicz, A. (1990). Eine pollenanalytische und moorkundlische Studie zur Vegetationgeschichte des Podhale-Gebites (West-Karpaten). Acta Paleobot., 30, 147-219.

Obidowicz, A. (1995). History of vegetation of the Podhale area. In W. Schirmer (Ed.), Quaternary field trips in Central Europe (pp. 334-335). Berlin: INQUA.

Pielou, E.C. (1975). Ecological diversity. New York: John Wiley \& Sons.

Riedel, A. (1988). Land snails (Gastropoda terrestia) (in Polish). Katalog Fauny Polski, 3, 3-316.

Ralska-Jasiewiczowa, M. (1988). Vegetation history and human impact in the Polish Carpathians. In L. Starkel, J. Rutkowski \& M. Ralska-Jasiewiczowa (Eds.), Late Glacial and Holocene Environmental Changes, Vistula Basin. Excursion Guide Book (pp. 73-76). Cracow: Wydawnictwa Akademii Górniczo-Hutniczej.

Ralska-Jasiewiczowa, M. \& Starkel L (1988). Record of the hydrological changes during the Holocene in the lake, mire and fluvial deposits of Poland. Folia Quaternaria, 57, 91-127.

Rousseau, D.D., Limondin-Lozouet N. \& Puissegur J.J. (1992). Respondes of Holocene malacological communities to the climatic and to anthropogenic impacts on the environment. Comptes Rendus de l'Academie des Sciences, II(315), 1811-1818.

Shannon, C.E. \& Weaver W. (1949). The mathematical theory of communication. Urbana: University of Illinois Press.

Simpson, E.H. (1949). Measurement of diversity. Nature, 163, 668. DOI:10.1038/163688a0.

Starkel, L., Kalicki, T., Krąpiec M., Soja, R., Gębica P. \& Czyżowska E. (1996). Hydrological changes of valley floor in the Upper Vistula basin during Late Vistulian and Holocene. In L. Starkel (Ed.), Evolution of the Vistula river valley during the last 15000 years. Quaestiones Geographicae, Special Issue 9, 7-128.

Wolda, H. (1981). Similarity indices, sample size and diversity. Oecologia, 50, 296-302. DOI:10.1007/BF00344966. 